\title{
Digital media and the modern-day pet trade: a test of the 'Harry Potter effect' and the owl trade in Thailand
}

\author{
P. Siriwat ${ }^{1, *}$, K. A. I. Nekaris ${ }^{1,2}$, V. Nijman ${ }^{1}$ \\ ${ }^{1}$ Oxford Wildlife Trade Research Group, Oxford Brookes University, Oxford OX3 0BP, UK \\ ${ }^{2}$ Nocturnal Primate Research Group, Oxford Brookes University, Oxford OX3 0BP, UK
}

\begin{abstract}
We explored the influence of film and media on the exotic pet trade using the context of the 'Harry Potter effect' and the owl trade in Thailand as a case study. We compared the owl trade between market surveys dating from 1966 to 2019 in Bangkok's Chatuchak market, to online surveys from 2017 to 2019. Using generalised linear models, we examined whether prices offered for owls could be explained by variables linked to whether the species are featured in the Harry Potter franchise, body size, tameness and temporal/seasonal harvesting. We also tested for an anthropogenic Allee effect by examining the relationship between the availability of owls and asking price. Owls never exceeded $1.3 \%$ of the total number of birds for sale in Chatuchak animal market, and we did not observe any owls during our visits in 2011, 2018 and 2019. In contrast, we recorded 311 individuals of 17 species from 206 posts on the online marketplace on Facebook. Owls are offered for sale during all months of each year surveyed but more so from February to April; availability did influence price. We found that price was significantly explained by body mass, but not by association with the Harry Potter franchise or by tameness. We found that owls have become more popular as pets, and as they are potentially sourced from the wild, this inevitably causes conservation concerns. Owls are just one of many taxa suffering from the unregulated and accessible marketplace that social media sites offer to vendors.
\end{abstract}

KEY WORDS: Owls $\cdot$ Strigiformes $\cdot$ Harry Potter $\cdot$ Wildlife trade $\cdot$ Facebook

\section{INTRODUCTION}

The influence of digital media, particularly films, on the wildlife trade is of increasing research interest (Yong et al. 2011, Militz \& Foale 2017, Nijman \& Nekaris 2017, Silk et al. 2018). Past studies have shown evidence that films featuring animals have influenced the popularity of such animals to be traded as pets. The effects observed are often complex and are not always direct. For example, certified registrations for Dalmatian breeds were found to increase by 6.2 -fold $7 \mathrm{yr}$ following the release of the film '101 Dalmatians' (Herzog et al. 2004), whereas after the release of the first 'Jurassic Park' film and the 'Teenage Mutant Ninja Turtle' television series,

${ }^{*}$ Corresponding author: siriwat.penthai@gmail.com there was a delayed spike in the global trade of reptiles from 1 to 3 yr later (Ramsay et al. 2007, Nijman \& Shepherd 2011). In the case of 'Finding Nemo', a film whose main character, Nemo, is a clownfish, it was initially reported that import volumes of clownfish species increased after the film's release in 2003 (Prosek 2010, Rhyne et al. 2012). Further studies, however, have suggested that the 'Nemo effect' was not significant after considering the overall increase in import and trade of marine aquarium fish (Militz \& Foale 2017). The 'Harry Potter' series by J. K. Rowling is another film franchise with a massive global audience. Owls, which feature prominently in these films, are considered messengers between the human and magical world and are pet companions to the

() The authors 2020. Open Access under Creative Commons by Attribution Licence. Use, distribution and reproduction are unrestricted. Authors and original publication must be credited. 
main characters (Nijman \& Nekaris 2017). For instance, Harry Potter has a snowy owl Bubo scandiacus named Hedwig, while his best friend, Ron Weasley, owns a common scops owl Otus scops.

This film franchise led to testing the 'Harry Potter effect', a phenomenon whereby the presence of owls in the films normalises the keeping of owls as pets, with a resulting increase in the trading of, and in the keeping of, owls as pets (Nijman \& Nekaris 2017). The Harry Potter effect is supported by anecdotal observations of increases in owl trading in India (Ahmed 2010), Indonesia (Shepherd 2012), Thailand (Chng \& Eaton 2015) and Japan (Vall-Llosera \& Su 2019). Panter et al. (2019) recently reported an increase in global international trade in owls towards the end of the 1990s and early 2000s, coinciding with the release of the first Harry Potter books and film, but noted that this occurred coincidentally with a general increase in the international raptor trade and the global expansion of the Internet and social media.

Two research groups have studied the Harry Potter effect quantitatively, one in a country where trade in owls is either prohibited or strictly regulated (Indonesia) and one where owls can be traded legally (UK). Nijman \& Nekaris (2017) compared the bird trade in open markets in Indonesia before (1979-2010) and after (2012-2016) the release of the Harry Potter books and films, and found an increase in the number of species of owls offered, an increase in the absolute number of owls for sale and an increase in owls as a proportion of the total number of birds in the markets (Nijman \& Nekaris 2017). There was a clear time-lag between the release of the films and books and the increase in the owl trade, suggesting a delayed Harry Potter effect. Finally, Nijman \& Nekaris (2017) found that common species (i.e. the ones offered in greater numbers in the markets) were cheaper than the rarer ones, irrespective of size, suggesting a possible anthropogenic Allee effect, whereby a premium is placed on rarer species (Courchamp et al. 2006, Holden \& McDonald-Madden 2017).

Megias et al. (2017) did not find a Harry Potter effect based on official owl ownership statistics and potential independent variables for drivers of demand such as UK box-office and book sales. Likewise, they did not find strong support to suggest that the end of the Harry Potter series had a noticeable impact on the number of pet owls handed over to UK wildlife sanctuaries. Despite the differences in finding support for a Harry Potter effect on owl keeping, both Nijman \& Nekaris (2017) and Megias et al. (2017) voiced concerns over the realised and per- ceived impacts that the films may have on trade and species conservation, and the need for further research to understand films as drivers of the wildlife trade (Militz \& Foale 2017, Vesper 2017).

Quantifying the relationship between digital media (i.e. films) and demand for certain species as a wildlife trade driver is challenging, and requires long-term data for in-depth understanding. Market surveys have traditionally been one of the main methods to gather data on the trade of a species (Cheung \& Dudgeon 2006, Regueira \& Bernard 2012, Nijman \& Shepherd 2015). More recently, the Internet and social media platforms have shifted the way wildlife is traded legally and illegally (Lavorgna 2014). As a result, research is being increasingly focussed on online trade, including markets for orchids (Hinsley et al. 2016), reptiles (Sung \& Fong 2018), mammals (Siriwat \& Nijman 2018) and birds (Alves et al. 2013). Beyond identifying the scope and scale of the trade, studies on the Internet provide insight into understanding consumer preferences and demand (Sung \& Fong 2018).

Thailand has been one of the countries known as a hub for both legal and illegal wildlife trade, with a well-documented long-term history of market surveys recording the bird trade since the 1960s (McClure \& Chaiyaphun 1971, Round 1990, Chng \& Eaton 2015). The combination of loosely monitored online trade and the 46 million Facebook users in the country has also made Thailand a key study area (Phassaraudomsak \& Krishnasamy 2018, Siriwat \& Nijman 2018). Here, we report on the trade of owls in Thailand in 2 different market places: the traditional physical brick-and-mortar markets and online markets. We predicted that availability, links to the Harry Potter books and films, body size, and tameness are factors that affect price. Although we did not find a direct Harry Potter effect on the trade of owls in Thailand, we demonstrate that owls are becoming increasingly available, and the unregulated nature of the trade is a serious conservation concern.

\section{MATERIALS AND METHODS}

\subsection{Data acquisition}

We surveyed Bangkok's main bird market, the Chatuchak weekend market (also known as JJ market), for the presence of owls in June 2011 (2 visits) and December 2018 and February 2019 (3 visits). In Thailand, previous bird market surveys have mainly been conducted in this market. We compiled data 
from McClure \& Chaiyaphun (1971), Round (1990), Nash (1993), Round \& Jukmongkkol (2003) and Chng \& Eaton (2015). We recorded survey dates, number of visits, total birds observed, and species and number of owls observed and then calculated the number of owls as a proportion of all birds traded in this market.

We searched online for exotic pet groups in Thai and English and located 9 Facebook groups. We monitored the online trade of owls on Facebook over a 24 mo period from April 2017 to March 2019. Each group could be searched by anyone with a Facebook account. In cases where groups required approval from administrators to join, the interaction was limited to simply requesting approval. Since each group acted as a 'market platform' for buying and selling wildlife, we used a typical economic market approach and implemented market survey protocols in each monitoring session (see Barber-Meyer 2010, Nekaris et al. 2010). Due to the potentially sensitive content, we followed the guidelines of Roulet et al. (2017) to conduct covert observations. We did not interact with any participants and only collected openly available information. We abided by the website's terms and conditions and followed ethical guidelines and anonymised data after cross-checking the data for duplicates, so as not to publish any information that could be attributed to an individual (cf. Kosinski et al. 2015, Martin et al. 2018). Only 1 group focussed primarily on birds, and the remaining 8 groups focused on a variety of taxa of exotic pets. The number of members in each group ranged from 4080 to 26851 , with an average of 17200 members.

From April 2017 to March 2019, we collected data on the owls for sale, which included details on species, number of individuals, price, date and any information that informed on trade methods (cf. Siriwat \& Nijman 2018). We carried out monitoring on a monthly basis. To determine our monitoring sessions, we used the Facebook group photo limit approach, whereby Facebook limits group pages to 5000 pictures at any given time (cf. Iqbal 2016). We anonymised data and saved pictures of owls in order to cross-reference duplicate posts to minimise double-counting. We removed birds that were unidentifiable (i.e. very young chicks) from further analyses.

We followed the taxonomy of Eaton et al. (2016) and König \& Weick (2008), with the exception of the Australasian barn owl Tyto javanica, which we recognise as a species (Aliabadian et al. 2016). We collected price data in Thai Baht (THB), presented here in US\$ based on a mean conversion rate of THB $32.8=$ US\$ 1 (exchange rate ranged from 31.1 to 34.5 THB within the monitoring period).

\subsection{Analysis}

We conducted analyses on the number of sales posts and number of individuals traded. In the analyses, we highlighted the composition of species being traded and developed hypotheses to explore the price dynamics (Table 1). We used a generalised linear model (GLM) in R Version 3.2.1 (R Core Team 2018). For analysis, we classified owls as 'featured in the Harry Potter films or species similar to those featured in Harry Potter films' (based on colour and size) and 'not featured in Harry Potter films'. Additionally, we also incorporated other variables into the model in an attempt to explain the price. These variables included the availability (number of individuals posted for sale), body size (mass), temporal factor (month) and a tameness variable (advertisements using terms related to 'tame', 'egg-reared', or 'friendly' to describe owls offered for sale). We also tested for an anthropogenic Allee effect (Courchamp et al. 2006, Holden $\&$ McDonald-Madden 2017), where we examined the

Table 1. Factors included in the generalised linear model to explain prices for owls traded on Facebook in Thailand

\begin{tabular}{|c|c|}
\hline Factor & Hypothesis \\
\hline ‘Harry Potter effect' & $\begin{array}{l}\text { Owls with links to species featured in the Harry Potter film franchise will be acknowledged } \\
\text { as such in the advertisements, and these popular featured owls will be more expensive. }\end{array}$ \\
\hline Number of owls & When more owls are available, the prices of individual owls will decrease. \\
\hline Seasonality & $\begin{array}{l}\text { The number of owls traded is linked to natural availability or breeding cycles of owls, which } \\
\text { will be reflected in seasonality. During seasons with fewer owls available, owls will be more } \\
\text { expensive. }\end{array}$ \\
\hline Size & Larger owls will be sold for higher prices. \\
\hline Tameness & Owls advertised as 'egg-raised' or 'tame' will be sold at a higher price. \\
\hline Anthropogenic Allee effect & $\begin{array}{l}\text { Species that are rare (and thus less available on the market) will be more expensive. The same } \\
\text { pattern will occur within species, whereby prices will be higher in months with fewer posts. }\end{array}$ \\
\hline
\end{tabular}


relationship between price and availability (number of posts and number of individuals posted for sale), both between species and within the same species (comparing monthly price data). We assumed a normal distribution for the response variable (price) and $\log$-transformed continuous variables. We report $t$ values from the GLMs and associated p-values. To explore the effect of time of year on the owl trade, we tested if the number of posts and number of owls were equally distributed over the 12 months of the year. We also explored whether asking prices during months with significantly more owls for sale dropped and, conversely, if asking prices during months with significantly fewer owls for sale increased.

The first Thai book translation of Harry Potter came out in the same year as the English version in 1997, followed by the first film in 2001. The final instalment of the film came out in 2011. We use this period (19972011) as the transition period.

\section{RESULTS}

\subsection{Owl presence in the brick-and-mortar bird market}

We did not observe any owls in Chatuchak during our visits in 2011, 2018 or 2019. Nash (1993) likewise did not record any owls during any of his visits to this market. In contrast, McClure \& Chaiyaphun (1971), Round (1990), Round \& Jukmongkkol (2003) and Chng \& Eaton (2015) recorded a total of 402 owls. With close to 750000 wild-caught birds recorded in Chatuchak, overall, owls rarely made up more than $0.5 \%$ of the total number of birds for sale; an exception was a $1 \mathrm{~d}$ visit by Chng \& Eaton (2015), who recorded 17 owls of 3 species, making up $1.3 \%$ of the total that day (1271 birds). Based on previous market surveys, owls represent a small fraction of the total birds traded in Thai markets (Fig. 1a). We found no
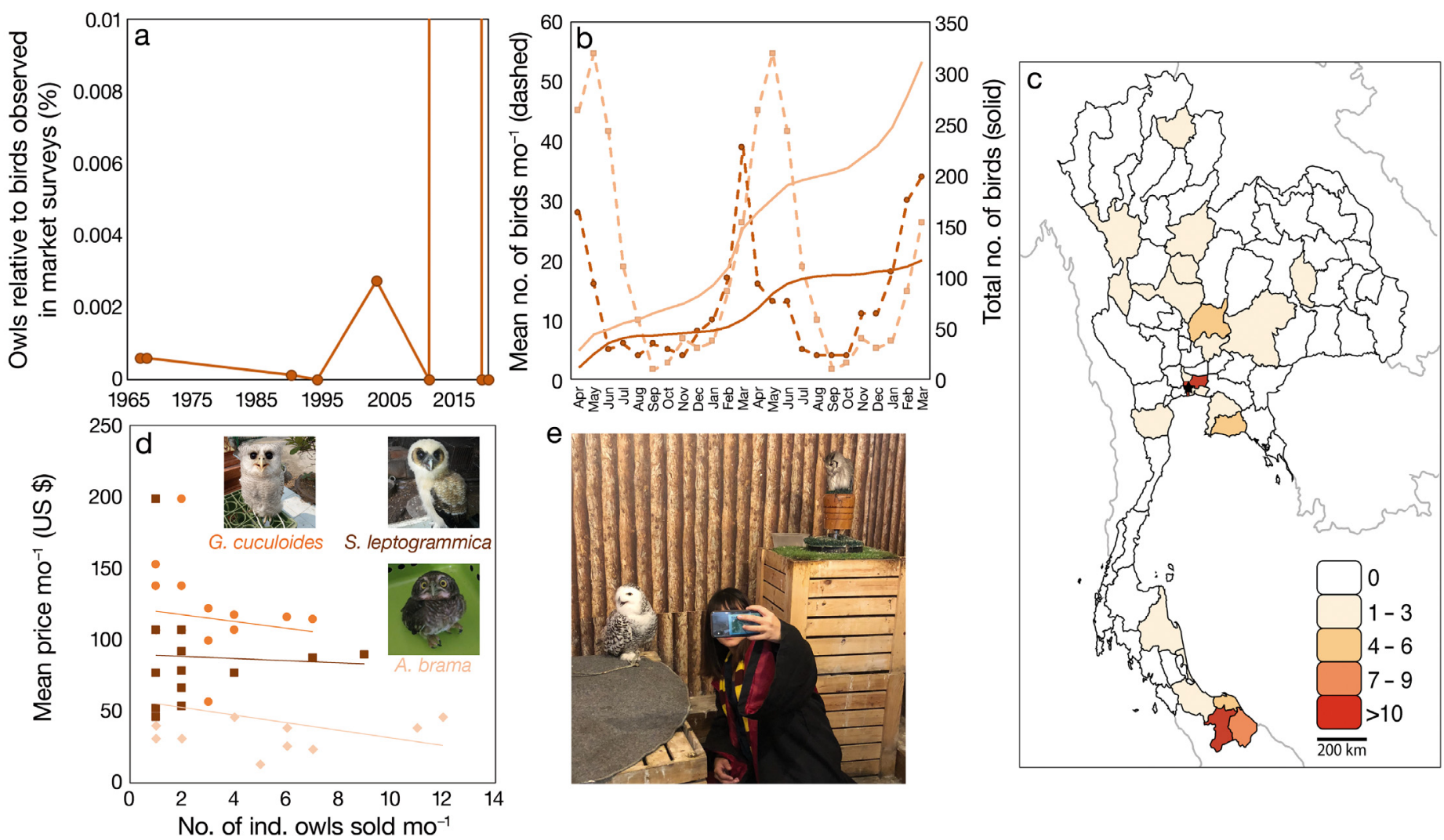

Fig. 1. (a) Percentage of owls relative to all birds observed as reported from 6 market surveys between 1966 and 2019 . In their market survey, Chng \& Eaton (2015) reported that owls contributed to $1.3 \%$ of all birds for sale (off the scale in this figure). (b) Observed seasonality recorded in this study (April 2017 to March 2019; orange) compared to McClure \& Chaiyaphun (1971) (November 1966 to January 1969; brown), represented in the number of owls traded per month (dashed) and total number of owls sold (solid line). (c) Distribution of posts throughout Thailand where province data were available. (d) Availability and price of the 3 most commonly traded species, spotted owlet Athene brama, barred eagle-owl Glaucidium cuculoides and brown wood owl Strix leptogrammica. (e) Guests dressed up in Harry Potter-themed props pose for a selfie with a snowy owl Bubo scandiacus (left) named 'Hedwig' and a northern white-faced owl Ptilopsis leucotis (right) on display in a themed café in Bangkok 
significant overlap in the percentage of owls or the absolute number of owls observed with the period during which Harry Potter films or books were first released (2001-2011). Thus, we found little evidence of a 'Harry Potter effect' on the owl trade within Chatuchak Market.

\subsection{Online market survey}

During the Facebook surveys from April 2017 to March 2019, we recorded 311 individual owls of 17 species from 206 posts during 39 monitoring sessions (Table 2, Fig. 1b). Of the 17 species, 14 are native to Thailand and are listed as protected species in Thailand. Two posts (4 individuals) were unidentifiable, as the pictured owls were too young and there was insufficient description to aid in species identification. Prices for individual owls ranged from US\$ 12 to US\$ 1676. The barred eagle-owl Bubo sumatranus ac- counted for most of the trade by posts $(\mathrm{n}=36)$, while the spotted owlet Athene brama was the most popular by individual count $(\mathrm{n}=60)$. For about half of the posts $(n=104)$, geographic origin of the seller was provided; these posts originated from 20 provinces around the country (Fig. 1C). Most posts originated from Bangkok, the capital city $(\mathrm{n}=32)$ and Yala, the southern-most province of Thailand $(n=31)$. Five international sellers advertised on Thai Facebook pages, with 3 posts from Indonesia, and 2 posts from Malaysia.

We qualitatively observed that owls were not traded in equal numbers throughout the year, as was also the case in the market surveys of McClure \& Chaiyaphun (1971) that were conducted over 82 weekends from November 1966 to January 1969 (Fig. 1b). The number of posts and number of individual owls that were recorded for sale were not equally distributed over the 12 months (posts: $\chi^{2}=68.37 .49$, $\mathrm{df}=11, \mathrm{p}<0.001$; individuals: $\chi^{2}=166.49, \mathrm{df}=11, \mathrm{p}<$ 0.001; Table 3). In the months of February to April,

Table 2. Summary of owl species traded on Facebook in Thailand as monitored over the 24 mo study period. Mean mass obtained from König \& Weick (2008). All identified owl species are classified as 'Least Concern' on the IUCN Red List, with the exception of the snowy owl Bubo scandiacus, which is listed as 'Vulnerable'

\begin{tabular}{|c|c|c|c|c|c|}
\hline Species & $\begin{array}{c}\text { Mean } \\
\text { mass }(\mathrm{g})\end{array}$ & $\begin{array}{c}\text { Harry Potter } \\
\text { species }\end{array}$ & $\begin{array}{l}\text { No. of } \\
\text { posts }\end{array}$ & $\begin{array}{c}\text { No. of } \\
\text { individuals }\end{array}$ & $\begin{array}{l}\text { Price in US\$ } \\
\text { (mean } \pm \text { SD) }\end{array}$ \\
\hline Spotted owlet Athene brama & 113 & No & 27 & 60 & $45 \pm 20$ \\
\hline Snowy owl Bubo scandiacus & 1925 & Yes & 2 & 2 & 884 \\
\hline Barred eagle-owl B. sumatranus & 1257 & Yes & 45 & 45 & $116 \pm 40$ \\
\hline Northern great horned owl $B$. virginianus & 58 & Yes & 1 & 1 & $1677 \pm 4$ \\
\hline Buffy fish owl B. ketupu & 1564 & No & 27 & 31 & $83 \pm 29$ \\
\hline Brown hawk-owl B. zeylonensis & 200 & No & 5 & 7 & $36 \pm 18$ \\
\hline Collared owlet Glaucidium brodiei & 163 & No & 2 & 4 & 37 \\
\hline Asian barred owlet $G$. cuculoides & 282 & No & 11 & 29 & $21 \pm 23$ \\
\hline Collared scops owl Otus lettia & 139 & Yes & 1 & 7 & Not available \\
\hline Mountain scops owl O. spilocephalus & 69 & Yes & 1 & 1 & 24 \\
\hline Oriental scops owl $O$. sunia & 85 & Yes & 15 & 29 & $31 \pm 21$ \\
\hline Northern white faced owl Ptilopsis leucotis & 204 & No & 5 & 7 & 899 \\
\hline Brown wood owl Strix leptogrammica & 950 & No & 33 & 38 & $88 \pm 33$ \\
\hline Spotted wood-owl S. seloputo & 1011 & No & 15 & 25 & $86 \pm 13$ \\
\hline Oriental bay owl Phodilus badius & 365 & No & 5 & 7 & 27 \\
\hline Australasian barn owl Tyto javanica & 41 & Yes & 7 & 13 & 41 \\
\hline Eastern grass owl T. longimembris & 130 & No & 1 & 1 & $28 \pm 4$ \\
\hline Unidentifiable & & & 2 & 4 & \\
\hline
\end{tabular}

Table 3. Seasonality in trade and asking prices of owls in Thailand (mean \pm SD), showing that in the peak season from February to April, when more owls are offered for sale, prices are lower for 2 of the 3 most commonly traded species, and the opposite is observed during the low season from August to October

\begin{tabular}{|lcccc|}
\hline Trade & Sample size (N) & 24 mo period & February-April & August-October \\
\hline All owls (ind. $\mathrm{mo}^{-1}$ ) & 311 & $13.0 \pm 10.3$ & $27.3 \pm 9.2$ & $4.5 \pm 0.8$ \\
All owls (no. posts $\mathrm{mo}^{-1}$ ) & 206 & $8.6 \pm 5.8$ & $16.0 \pm 5.9$ & $4.0 \pm 1.1$ \\
Spotted owlet (monthly asking price, US\$) & 60 & $45.1 \pm 30.3$ & $41.7 \pm 33.9$ & $58.9 \pm 41.6$ \\
Barred eagle-owl (monthly asking price, US\$) & 44 & $116.4 \pm 31.5$ & $106.6 \pm 5.3$ & $116.9 \pm 35.2$ \\
Brown wood owl (monthly asking price, US\$) & 38 & $88.1 \pm 37.6$ & $67.9 \pm 19.9$ & 106.7 \\
\hline
\end{tabular}


significantly more owls were offered for sale than in the other months combined $\left(\chi^{2}=127.57, \mathrm{df}=1, \mathrm{p}<\right.$ 0.0001), whereas in August to October, significantly fewer owls were for sale than in the other months combined $\left(\chi^{2}=44.16, \mathrm{df}=1, \mathrm{p}<0.001\right)$.

For the 3 commonly traded species for which we had sufficient price data, we tested whether asking prices were influenced by availability (Table 3). All 6 outcomes were in the predicted direction (lower prices during high availability, higher prices during low availability); (binomial test, $\mathrm{p}=0.04$ ). Spotted owlets were not cheaper during the 3 mo period when significantly more spotted owls were offered for sale compared to the other months combined $\left(\chi^{2}=0.25\right.$, $\mathrm{df}=1, \mathrm{p}=0.617)$, but they were more expensive when fewer owls were advertised $\left(\chi^{2}=4.22\right.$, df $=1, \mathrm{p}=$ 0.040). Brown wood owls Strix leptogrammica were significantly cheaper during periods of high owl availability $\left(\chi^{2}=4.60, \mathrm{df}=1, \mathrm{p}=0.032\right)$ and significantly more expensive when few owls were offered for sale $\left(\chi^{2}=3.95, \mathrm{df}=1, \mathrm{p}=0.047\right)$, again when compared against the other 9 months of the year. Barred eagleowl prices were less influenced by availability $\left(\chi^{2}=\right.$ $0.83, \mathrm{df}=1, \mathrm{p}=0.362$ and $\chi^{2}=0.01, \mathrm{df}=1, \mathrm{p}=0.975$ for periods of high and low owl availability, respectively).

We did not observe a shift in species composition between the physical bird markets and the online bird market (Table 4). Comparison with surveys conducted by Round (1990), Nash (1993) and Chng \& Eaton (2015) were less meaningful, as they recorded far fewer species and individuals than we did; however, data from McClure \& Chaiyaphun (1971) allowed for comparison between studies. We did not find statistically significant variation in genera surveyed for sale in the study by McClure \& Chaiyaphun (1971) and in our study ( $t$-test, $\left.t_{8}=1.12, \mathrm{p}=0.29\right)$. Overall, the composition and distribution of species listed for

Table 4. Comparison of species composition as observed from physical markets recorded in the late 1960s (McClure \& Chaiyaphun 1971) and on online platforms recorded in the present study (2017-2019)

\begin{tabular}{|lcc|}
\hline $\begin{array}{l}\text { Genus (no. of } \\
\text { species recorded) }\end{array}$ & $\begin{array}{c}\text { 1966-1969 } \\
\text { (no. of ind.) }\end{array}$ & $\begin{array}{c}\text { 2017-2019 } \\
\text { (no. of ind.) }\end{array}$ \\
\hline Otus (4) & 30 & 37 \\
Ptilopsis (1) & 0 & 7 \\
Bubo (8) & 116 & 86 \\
Strix (2) & 56 & 63 \\
Glaucadium (2) & 8 & 31 \\
Athene (1) & 89 & 60 \\
Ninox (1) & 26 & 0 \\
Phodilus (1) & 6 & 7 \\
Tyto (3) & 44 & 14 \\
\hline
\end{tabular}

sale were similar. However, more owlets (Glaucadium spp.) were recorded in our online study compared to the surveys in Chatuchak, whereas conversely, McClure \& Chaiyaphun (1971) recorded more barn owls (Tyto spp.) for sale.

\subsection{Harry Potter effect and price variation}

Based on the species' GLMs, we found that price significantly explained the number of individuals available $\left(t_{11}=-2.36, p=0.038\right)$, whereby more common owls were less expensive. We did not find a statistically significant relationship with body mass $\left(t_{11}=\right.$ $1.79, \mathrm{p}=0.10)$ or with a Harry Potter association $\left(t_{11}=\right.$ $-0.84, \mathrm{p}=0.43)$ at the species level. In 8 posts $(5 \%)$, descriptive terms related to Harry Potter were mentioned either in the sale advertisement or in the comments, such as 'Hedwig' or 'Harry's owl'. This type of description was seen for 2 species of imported owls (snowy owl Bubo scandiacus and northern whitefaced owl Ptilopsis leucotis), and 1 post for the Asian barred owlet G. cuculoides.

In an attempt to explain price further, we also conducted the GLM analyses at the individual level. We modelled price with owl body mass, count or availability, Harry Potter association and domestication or tameness. We found that the only factor that significantly explained price was body mass $\left(t_{135}=7.04, \mathrm{p}<\right.$ $0.01)$. A high number of posts $(n=80)$ included statements linked to domestication or tameness, such as 'friendly' or 'egg-reared', but we did not find these terms to be a statistically significant explanatory factor of price $\left(t_{135}=-0.61, p=0.54\right)$. Likewise, we found no effect on asking prices of whether the species for sale was featured in the Harry Potter films or was a species similar to one that was in the films $\left(t_{135}=\right.$ $-0.39, p=0.70$ ). In testing for an anthropogenic Allee effect, we assessed price relationships with availability (number of posts and number of individuals posted for sale) between species and within 3 of the most commonly traded species. Including all species, we did not find a significant relation between price and number of posts (linear regression, $F_{1,22}=0.0017$, $\mathrm{p}=0.97)$ and number of owls for sale $\left(F_{1,22}=0.06, \mathrm{p}=\right.$ 0.81 ). For the 3 species where $>12$ mo of data were available, we did not find a statistical relationship between price and availability either for the number of posts or for the number of owls for sale (spotted owlet $\left[F_{1,10}=1.38, \mathrm{p}=0.27 ; F_{1,10}=1.20, \mathrm{p}=0.29\right]_{\text {; }}$ barred eagle-owl $\left[F_{1,15}=0.27, \mathrm{p}=0.61 ; F_{1,15}=0.85\right.$, $\mathrm{p}=0.38] ;$ brown wood owl $\left[F_{1,12}=0.03, \mathrm{p}=0.86\right.$; $\left.F_{1,12}=0.03, \mathrm{p}=0.86\right]$; Fig. $1 \mathrm{~d}$ ). 
The trade in imported or non-native species contributed to less than $5 \%$ (7/151) of posts and only $4 \%$ by individuals traded. The average price for the 2 CITES-listed species, i.e. the northern white-faced owl and the snowy owl, was at US\$ 891 compared to the average price of domestic owls at US\$ 65. Of the 7 posts offering these CITES-listed species for sale, only 3 offered specific importation documentation.

\section{DISCUSSION}

We found that owls are traded on Facebook in Thailand, but we did not find unequivocal evidence for the 'Harry Potter effect' within the owl trade. Compared to the only other study that examined a general online trade (Phassaraudomsak \& Krishnasamy 2018), we found 5 additional species of owls traded, making a total of 15 species. Although there are limitations such as methodological differences or gaps in time, in making comparisons between market and online surveys, and even between online surveys, the overlap of 10 species from the 2 online surveys may reflect commonly sold species. The data shown here in the $2 \mathrm{yr}$ data set are more than what has been observed in physical market surveys in the past few decades, suggesting an increase in, or at least an expansion of, the owl trade with subsequent conservation implications.

A few studies have directly compared the trade of wildlife between traditional and online market surveys. For Thailand, we only have online prices and traditional market prices for 1 species of owl, the spotted owlet, as Chng \& Eaton (2016) recorded a price of US\$ 15 in Chatuchak market. In contrast, we recorded prices between US\$ 12 and US\$ 106, averaging US\$ 45. Nijman \& Nekaris (2017) compared asking prices of owls offered for sale in Indonesian physical bird markets with those online. They found that for 1 species (spotted wood owl Strix seloputo) prices were higher online, for 2 species (buffy fish owl Bubo ketupu and Javan owlet Glaucidium castanopterus) prices were lower, and for 4 other species, there was no price difference. Nijman et al. (2019) analysed market and online surveys of the wild cat trade in 8 countries on 3 continents and revealed that in some countries, wildlife trade is indeed shifting to online platforms. However, the rate of this shift to online platforms depends on external factors such as a country's Internet penetration rate, or enforcement of protected species legislation inside physical markets (Nijman et al. 2019). For diurnal raptors, a clear shift of trade in physical bird markets to online platforms was reported in Indonesia. Birds of prey, including globally threatened species, were commonly traded in the bird markets Java and Sumatra in the 1990s to 2000s (Shepherd 2006, Nijman et al. 2009), but at present very few are recorded (Chng et al. 2015, Harris et al. 2015, Chng \& Eaton 2016, V. Nijman unpubl. data). In contrast, Iqbal (2016) and Gunawan et al. (2017) reported that in recent years, a large number of individuals of over 2 dozen species of raptor were now frequently offered for sale on online platforms.

Owl parts (talons, skulls, feathers, bones and meat) have historically been harvested for use in traditional medicine, for superstitious beliefs and the wild meat trade (Shepherd \& Shepherd 2009, Williams et al. 2014, Padhy 2016). Televised news media have popularised the religious activity of sacrificing of owls in India during the Diwali light festival, and this has led to an increase of owls in markets in the lead-up to the festival; in some cases, vendors even offer homedelivery services of owls (Padhy 2016). Furthermore, anecdotal reports suggest an increase in trade of live owls in markets in Indonesia (Nijman \& Nekaris 2017), and dead owls in Malaysia (Shepherd \& Shepherd 2009) and in India for medicinal use (Ahmed 2010).

The perception of owls has changed following their association with Harry Potter. Although without direct statistical correlation, we found explicit references to 'Harry Potter' or 'Hedwig owl', when referring to the exotic species of owls. Differences in culture must also be considered to gain a better understanding of the role or impact of the Harry Potter books and films, or indeed any other film franchise. Even though Megias et al. (2017) found no Harry Potter effect on owl keeping in the UK, it is crucial to closely monitor trade trends in countries which have both growing affluence and accessibility for exotic or otherwise unusual pets as well as weaker law enforcement and fewer social stigmas on keeping legally protected and globally threatened species (Nijman \& Nekaris 2017).

The 'Harry Potter effect' has visibly created a phenomenon in 'themed' cafés, many of which feature owls on display with Harry Potter props that have emerged in cities throughout Japan, Malaysia and Bangkok (Fig. 1e). For example, in Japan, these dedicated bird cafés have resulted in increased imports of captive-bred owls, despite strict legal constraints (Vall-Llosera \& Su 2019). The display of owls and use of Harry Potter props reflect that the association of owls and the film franchise has become normalised, and perhaps even symbolic in many communities. Even decades after their release, the impacts of globally influential films such as the Harry Potter franchise, with their associated wildlife, both in reality 
and perceived, are still worthy of exploration (Militz \& Foale 2017, Nijman \& Nekaris 2017).

It is also critical to remark in the impact of unregulated online trade in owl species in general. The observed seasonality is an indicator that owls may be sourced from the wild, either taken as eggs or through wild-trapping. These collection methods are a conservation concern, as unregulated harvesting may have potential implications on the viability of the wild population (Daut et al. 2015). Seasonality in the trade appeared to be associated with availability in the wild, following the natural breeding cycles of owls (Lenton 1984, König \& Weick 2008, Robson 2008). Seasonality in the trade of bird species was also observed in physical markets, which showed an extended breeding period in Thailand from March to August in which more nestlings and fledglings were offered for sale (McClure \& Chaiyaphun 1971). These previous results are consistent with our findings. Owl species are top predators that play a key role in the ecosystems where they are found (Comay \& Dayan 2018). Owl species with ranges in Thailand are also protected from trade under Thai wildlife laws; the continuing online trade, however reflects a lack of law enforcement or monitoring within the easily accessible virtual markets (Siriwat \& Nijman 2018). In the USA, owls were recognised as the most popular taxon of birds from an assessment of public interest within cultural niches (Schuetz \& Johnston 2019). Therefore, until more research is conducted on the impact of hunting on the ecosystem, the harvesting of owls for the pet trade must be monitored. Considering the fast-moving nature of these online platforms, the Thai state should cooperate directly with operators and consumers to raise awareness on the legality of the trade.

The trade in native vs. non-native species in the physical markets and the online platforms in Thailand appears to differ markedly between taxa. We only noted 5 posts of owl species that were nonnative to Thailand and that were either imported into the country or that were the offspring of owls imported previously. We have no evidence to suggest that any of the species native to Thailand were sourced from anywhere else than Thailand, and as such less than $5 \%$ of the total number of owls in the online trade were sourced abroad. These values are somewhat comparable to those found in another online study (Phassaraudomsak \& Krishnasamy 2018) but differ considerably from studies conducted in the Chatuchak animal market. Siriwat et al. (2019) reported that $80 \%$ of primates and carnivores traded for sale online in Thailand were species that were found in Thailand. In Chatuchak, Chng \& Eaton (2016) found that $44 \%$ of bird species and $45 \%$ of the individual birds offered for sale were not native to Thailand, and Nijman \& Shepherd (2015) found that $97 \%$ of the turtles and tortoises on sale belonged to non-native species. Todd (2011) found 32 Malagasy species (reptiles, amphibians, mammals) offered for sale during a 1 mo survey in 2010 in Chatuchak market.

A few comprehensive studies have taken an alternative approach that focussed on the role of social media platforms on wildlife demand or perceptions towards keeping wild animals as pets, where response to wildlife content was strategically analysed on platforms such as YouTube and Twitter (Nekaris et al. 2013, Radford et al. 2018, Clarke et al. 2019). These studies showed that a species' exoticness has a strong influence on creating 'viral' content. An example of this trend is the uncritical sharing of exotic pet or wildlife content on the Internet that may lead to misperceptions about wild animals. In 2009, comments on a YouTube video that showed a pet pygmy slow loris Nycticebus pygmaeus being tickled were analysed, and the authors found that the video content incentivised people to want slow lorises as pets, despite slow lorises being an Appendix I-listed species and classified as Vulnerable on the IUCN Red List (Nekaris et al. 2013). Furthermore, in 2016, a short clip of a habituated ring-tailed lemur Lemur catta was circulated, reaching over 20 million viewers within a few weeks. This post similarly led to a marked increase in search trends for 'lemurs' but also to an increase in direct references to 'wanting a lemur' pet (Clarke et al. 2019; see also Reuter et al. 2018).

Although we have primarily highlighted how digital media potentially contribute to the demand for wildlife as pets, it is essential to emphasise the potential benefits of digital media. Digital media can be used positively for conservation when shared strategically between the conservation community and the movie industry. For example, films can offer a vital opportunity to address the perception of wildlife species and can encourage audience engagement for conservation issues (Silk et al. 2018). Furthermore, equipped with education materials, films can also produce positive outcomes (Yong et al. 2011). There is a growing body of literature that links digital media and sentiments related to conservation, and this may even extend beyond the wildlife trade to address other global environmental issues, such as climate change (Lowe et al. 2006, Sakellari 2015). Whether in the form of film or on social media platforms, it is our responsibility to consume content conscientiously and at the very least, to be aware of conservation issues associated with wild animal content (Nekaris \& Campbell 2012). 
Acknowledgements. We thank Nern Siriwat, Somo Wimolset and Ratee Thesthong for their assistance in conducting market surveys, and Betty Betrex and Dino Kroos for their support during write-up. We also thank the 3 anonymous reviewers for their helpful comments. This research did not receive any specific grant from funding agencies in the public, commercial or not-for-profit sectors.

\section{LITERATURE CITED}

Ahmed A (2010) Imperilled custodians of the night: a study on illegal trade, trapping and utilization of owls in India. TRAFFIC India/WWF India, New Delhi

Aliabadian M, Alaei Kakhki N, Mirshamsi O, Nijman V, Roulin A (2016) Phylogeny, biogeography, and diversification of barn owls (Aves: Strigiformes). Biol J Linn Soc 119:904-918

Alves R, Lima J, Araujo H (2013) The live bird trade in Brazil and its conservation implications: an overview. Bird Conserv Int 23:53-65

* Barber-Meyer SM (2010) Dealing with the clandestine nature of wildlife-trade market surveys. Conserv Biol 24: 918-923

Cheung SM, Dudgeon D (2006) Quantifying the Asian turtle crisis: market surveys in southern China, 2000-2003. Aquat Conserv 16:751-770

Chng SCL, Eaton JA (2015) Snapshot of an on-going trade: an inventory of birds for sale in Chatuchak weekend market, Bangkok, Thailand. BirdingASIA 25:24-29

Chng SC, Eaton JA (2016) In the market for extinction: eastern and central Java. TRAFFIC Southeast Asia, Petaling Jaya

Chng S, Krishnasamy K, Shepherd CR, Nijman V (2015) In the market for extinction: an inventory of Jakarta's bird markets. TRAFFIC Southeast Asia, Petaling Jaya

* Clarke TA, Reuter KE, LaFleur M, Schaefer MS (2019) A viral video and pet lemurs on Twitter. PLOS ONE 14:e0208577

Comay O, Dayan T (2018) What determines prey selection in owls? Roles of prey traits, prey class, environmental variables and taxonomic specialization. Ecol Evol 8:3382-3392

* Courchamp F, Angulo E, Rivalan P, Hall RJ, Signoret L, Bull L, Meinard Y (2006) Rarity value and species extinction: the anthropogenic Allee effect. PLOS Biol 4:e415

Daut EF, Brightsmith DJ, Mendoza PA, Puhakka L, Peterson MJ (2015) Illegal domestic bird trade and the role of export quotas in Peru. J Nat Conserv 27:44-53

Eaton JA, van Balen S, Brickle NW, Rheindt FE (2016) Birds of the Indonesian Archipelago: Greater Sundas and Wallacea. Lynx, Barcelona

Gunawan, Paridi A, Noske RA (2017) The illegal trade of Indonesian raptors through social media. Kukila 20:1-11

* Harris JBC, Green JM, Prawiradilaga DM, Giam X, Hikmatullah D, Putra CA, Wilcove DS (2015) Using market data and expert opinion to identify overexploited species in the wild bird trade. Biol Conserv 187:51-60

Herzog HA, Bentley RA, Hahn MW (2004) Random drift and large shifts in popularity of dog breeds. Proc R Soc B 271(Suppl 5):S353-S356

* Hinsley A, Lee TE, Harrison JR, Roberts DL (2016) Estimating the extent and structure of trade in horticultural orchids via social media. Conserv Biol 30:1038-1047

* Holden MH, McDonald-Madden E (2017) High prices for rare species can drive large populations extinct: the anthropogenic Allee effect revisited. J Theor Biol 429:170-180
Iqbal M (2016) Predators become prey! Can Indonesian raptors survive online bird trading? BirdingASIA 25: 30-35

König C, Weick F (2008) Owls of the world, $2^{\text {nd }}$ edn. Christopher Helm Publishers, London

Kosinski M, Matz S, Gosling S, Popov V, Stillwell DJ (2015) Facebook as a research tool for the social sciences: opportunities, challenges, ethical considerations, and practical guidelines. Am Psychol 70:543-556

KLavorgna A (2014) Wildlife trafficking in the Internet age. Crime Sci 3:5

Lenton GM (1984) The feeding and breeding ecology of barn owls Tyto alba in Peninsular Malaysia. Ibis 126: 551-575

Lowe T, Brown K, Dessai S, de França Doria M, Haynes K, Vincent K (2006) Does tomorrow ever come? Disaster narrative and public perceptions of climate change. Public Underst Sci 15:435-457

Martin RO, Senni C, D'Cruze NC (2018) Trade in wildsourced African grey parrots: insights via social media. Glob Ecol Conserv 15:e00429

McClure HE, Chaiyaphun S (1971) The sale of birds at the Bangkok Sunday Market, Thailand. Nat Hist Bull Siam Soc 24:41-78

* Megias DA, Anderson SC, Smith RJ, Veríssimo D (2017) Investigating the impact of media on demand for wildlife: a case study of Harry Potter and the UK trade in owls. PLOS ONE 12:e0182368

Militz TA, Foale S (2017) The 'Nemo effect': perception and reality of Finding Nemo's impact on marine aquarium fisheries. Fish Fish 18:596-606

Nash SV (1993) Sold for a song: the trade in Southeast Asian non-CITES birds. TRAFFIC International, Cambridge

Nekaris KAI, Campbell N (2012) Media attention promotes conservation of threatened Asian slow lorises. Oryx 46: 169-170

Nekaris KAI, Shepherd CR, Starr CR, Nijman V (2010) Exploring cultural drivers for wildlife trade via an ethnoprimatological approach: a case study of slender and slow lorises (Loris and Nycticebus) in South and Southeast Asia. Am J Primatol 72:877-886

Nekaris KAI, Campbell N, Coggins TG, Rode EJ, Nijman V (2013) Tickled to death: Analysing public perceptions of 'cute' videos of threatened species (slow lorises - Nycticebus spp.) on Web 2.0 Sites. PLOS ONE 8:e69215

Nijman V, Nekaris KAI (2017) The Harry Potter effect: the rise in trade of owls as pets in Java and Bali, Indonesia. Glob Ecol Conserv 11:84-94

Nijman V, Shepherd CR (2011) The role of Thailand in the international trade in CITES-listed live reptiles and amphibians. PLOS ONE 6:e17825

Nijman V, Shepherd CR (2015) Analysis of a decade of trade of tortoises and freshwater turtles in Bangkok, Thailand. Biodivers Conserv 24:309-318

* Nijman V, Shepherd CR, van Balen S (2009) Declaration of the Javan hawk eagle Spizaetus bartelsi as Indonesia's National Rare Animal impedes conservation of the species. Oryx 43:122-128

Nijman V, Morcatty T, Smith JH, Atoussi S and others (2019) Illegal wildlife trade-surveying open animal markets and online platforms to understand the poaching of wild cats. Biodiversity 20:58-61

*Padhy S (2016) Over-religious activity, a threat to biodiversity: a case study: save the owl (Aves: Strigidae). J Biodivers 7:104-109 
Panter CT, Atkinson ED, White RL (2019) Quantifying the global legal trade in live CITES-listed raptors and owls for commercial purposes over a 40 -year period. Avocetta 43:23-36

Phassaraudomsak M, Krishnasamy K (2018) Trading faces: a rapid assessment on the use of Facebook to trade in wildlife in Thailand. TRAFFIC, Petaling Jaya

Prosek J (2010) Beautiful friendship. Natl Geogr Mag 217: 120-124

Radford L, Alexander S, Waters S (2018) On the rocks: using discourse analysis to examine relationships between Barbary macaques (Macaca sylvanus) and people on Gibraltar. Folia Primatol 89:30-44

Ramsay NF, Ng PKA, O'Riordan RM, Chou LM (2007) The red-eared slider (Trachemysscripta elegans) in Asia: a review. In: Gherardi F (ed) Biological invaders in inland waters: profiles, distribution, and threats. Springer, Dordrecht, p 161-174

R Core Team (2019) R: a language and environment for statistical computing. R Foundation for Statistical Computing, Vienna. www.R-project.org

Regueira RFS, Bernard E (2012) Wildlife sinks: quantifying the impact of illegal bird trade in street markets in Brazil Biol Conserv 149:16-22

Reuter KE, Clarke TA, LaFleur M, Ratsimbazafy J and others (2018) Exploring the role of wealth and religion on the ownership of captive lemurs in Madagascar using qualitative and quantitative data. Folia Primatol 89: 81-96

Rhyne AL, Tlusty MF, Schofield PJ, Kaufman L, Morris JA Jr, Bruckner AW (2012) Revealing the appetite of the marine aquarium fish trade: the volume and biodiversity of fish imported into the United States. PLOS ONE 7: e35808

Robson C (2008) A field guide to the birds of South-east Asia. New Holland, London

Roulet TJ, Gill M, Stenger S, Gill DJ (2017) Reconsidering the value of covert research: the role of ambiguous consent in participant observation. Organ Res Methods 20: 487-517

Round PD (1990) Bangkok Bird Club survey of the bird and mammal trade in the Bangkok weekend market. Nat Hist Bull Siam Soc 38:1-43

Editorial responsibility: Nils Bunnefeld, Stirling, UK
Round PD, Jukmongkkol R (2003) A survey of the bird trade in and around the Bangkok weekend market. Bird Conservation Society of Thailand and WWF International Programme Thailand, Bangkok

Sakellari M (2015) Cinematic climate change, a promising perspective on climate change communications. Public Underst Sci 24:827-841

Schuetz JG, Johnston A (2019) Characterizing the cultural niches of North American birds. Proc Natl Acad Sci USA 116:10868-10873

Shepherd CR (2006) The bird trade in Medan, North Sumatra: an overview. BirdingASIA 5:16-24

Shepherd CR (2012) The owl trade in Jakarta, Indonesia: a spot check on the largest bird markets. BirdingASIA 18: 58-59

Shepherd CR, Shepherd LA (2009) An emerging Asian taste for owls? Enforcement agency seizes 1,236 owls and other wildlife in Malaysia. BirdingASIA 11:85

Silk MJ, Crowley SL, Woodhead AJ, Nuno A (2017) Considering connections between Hollywood and biodiversity conservation. Conserv Biol 32:597-606

Siriwat P, Nijman V (2018) Illegal pet trade on social media as an emerging impediment to the conservation of Asian otter species. J Asia-Pac Biodivers 11:469-475

Siriwat P, Nekaris KAI, Nijman V (2019) The role of the anthropogenic Allee effect in the exotic pet trade on Facebook in Thailand. J Nat Conserv 51:125726

Sung YH, Fong JJ (2018) Assessing consumer trends and illegal activity by monitoring the online wildlife trade. Biol Conserv 227:219-225

Todd M (2011) Trade in Malagasy reptiles and amphibians in Thailand. TRAFFIC Southeast Asia, Petaling Jaya

*Vall-Llosera M, Su S (2019) Trends and characteristics of imports of live CITES-listed bird species into Japan. Ibis 161:590-604

* Vesper I (2017) Has Harry Potter mania cursed Indonesia's owls? Nature 547:15

*Williams VL, Cunningham AB, Kemp AC, Bruyns RK (2014) Risks to birds traded for African traditional medicine: a quantitative assessment. PLOS ONE 9:e105397

Yong DL, Fam SD, Lum S (2011) Reel conservation: Can big screen animations save tropical biodiversity? Trop Conserv Sci 4:244-253

Submitted: June 7, 2019; Accepted: October 29, 2019

Proofs received from author(s): December 23, 2019 